\title{
W.
}

Journal of Rehabilitation Research

and Development Vol. 27 No. 2, 1990

Pages 163-170

\section{Wheelchair batteries II: Capacity, sizing, and life}

\author{
James J. Kauzlarich, PhD \\ University of Virginia, Rehabilitation Engineering Center, Charlottesville, VA 22903
}

\begin{abstract}
The characteristics of lead-acid batteries for wheelchairs in terms of a new empirical equation for the capacity, application of the Palmgren-Miner Rule for sizing the battery, and the effect of depth of discharge on the life cycles is presented. A brief section about selecting an economical battery for an electric wheelchair is included.
\end{abstract}

Key words: battery selection, electric wheelchairs, lead-acid batteries, Palmgren-Miner Rule, wheelchair batteries.

\section{INTRODUCTION}

The battery performance of electric wheelchairs was measured under indoor and outdoor conditions at the University of Virginia Rehabilitation Engineering Center, and the results reported in 1983 (7). In 1986, a similar study was conducted at the Energy Research Laboratory, Denmark, (9), that included the performance of lead-acid batteries commonly available in Europe. In both of these studies, it was reported that the battery was the most frequent cause of breakdown and the most limiting component of electric wheelchairs. Data from the Danish study (9) determined that the deep discharge tubular positive plate lead-acid wet cell was the most economical choice for an electric wheelchair (6). Currently, the tubular positive plate battery for wheelchairs is only available in Europe.

In this paper we are concerned with lead-acid batteries for wheelchairs, and in particular a method for characteriz-

Address all correspondence and requests for reprints to: James J. Kauzlarich, $\mathrm{PhD}$, University of Virginia, Mechanical and Aerospace Engineering Department, Thornton Hall, Charlottesville, VA 22903. ing the capacity of the battery under the variable discharge load of wheelchairs, sizing the battery in battery design, and the effect of depth of discharge (DOD) on life of the battery. We have extended and corrected an approach published previously (7).

\section{BATTERY CAPACITY}

The practical discharge capacity of the lead dioxide of the positive plate and the lead of the negative plate in a dilute solution of sulfuric acid electrolyte depends on many factors, but mainly on rate of discharge and much less on temperature. The primary capacity of interest is that of a single cell with discharge time defined as the time to reach a specified cut-off voltage. A single cell voltage is approximately 2 volts and cells in series connections are built into a battery, where common arrangements are 3 cells giving 6 volts, and 6 cells giving 12 volts. The available electrochemical energy of the cell is measured in watthours, but since the voltage does not change very much, the capacity in terms of ampere-hours is most often listed.

A number of empirical equations relating discharge current and time have been proposed, but only Peukert's equation proposed in 1897 (1, p.291) has found wide application. The Peukert equation relates current $I$ to time of discharge $t$, and is a power law equation given by

$$
\mathbf{r}^{\mathrm{n}} \mathrm{t}=\mathrm{C}
$$

where $\mathrm{n}$ and $\mathrm{C}$ are constants for a particular battery operating at a particular temperature. For very low currents, much lower than used by a wheelchair, as $\mathrm{I} \rightarrow 0$, 
Journal of Rehabilitation Research and Development Vol. 27 No. 2 Spring 1990

Equation [1] predicts that $t \rightarrow \infty$, which is physically unreal. At high currents, including currents used by wheelchairs, Peukert's equation does not fit the test data very well. We propose to use a new empirical equation for battery capacity in the form of

$$
\mathrm{Q}=\mathrm{Nit}=\mathrm{NA}(1+\alpha \mathrm{T}) \mathrm{B}^{\mathrm{i}} / \mathrm{i}^{\mathrm{n}-1}
$$

where $\mathrm{Q}$ is the capacity in terms of ampere-hours, $\mathrm{N}$ is the number of positive plates in the cell, $\mathrm{A}$ is a constant, $\alpha$ is the coefficient of temperature correction for capacity, $\mathrm{T}$ is temperature in degrees Celsius, $\mathrm{B}$ and $\mathrm{n}$ are constants, and $i$ is the current per positive plate in amperes. This equation, a modification of the Peukert equation, fits the cell or battery discharge curve more accurately at high currents. It incorporates the concept that the capacity of cells containing the same components but having a varying number of plates is proportional to the number of positive plates (3). The total current is related to the number of positive plates as

$$
\mathrm{i}=\mathrm{I} / \mathrm{N}
$$

Equation [2] can be manipulated for convenience of analysis to the form

$$
\mathrm{t}=\mathrm{A}(1+\alpha \mathrm{T}) \mathrm{B}^{\mathrm{I} / \mathrm{N}} /(\mathrm{I} / \mathrm{N})^{\mathrm{n}}
$$

and can be simplified further resulting in

$$
\mathrm{t}=\mathrm{K}_{0} \mathrm{~B}^{\mathrm{I} / \mathrm{I}^{\mathrm{n}}}
$$

where

$$
\mathrm{K}_{0}=\mathrm{AN}^{\mathrm{n}}(1+\alpha \mathrm{T}) / \mathrm{B}^{\mathrm{n}}
$$

Equation [5] can be used to describe the power versus discharge time of a battery by simply replacing the current $\mathrm{I}$ by power $\mathrm{P}$ and evaluating new constants for $\mathrm{K}_{0}$ and $\mathrm{B}$, so that

$$
\mathrm{t}=\mathrm{K}_{0} \mathrm{~B}^{\mathrm{P}} / \mathrm{P}^{\mathrm{n}}
$$

Figure 1 shows typical automotive LSI (lighting, starting, and ignition) battery discharge performance at 27 degrees Celsius in terms of current or power versus discharge time. Here it is shown that the deviation from Peukert's equation occurs above 20 amperes or watts, which is well within the operating region of interest for wheelchairs. Because the equations fitted to the curves by the least-squares method are empirical, there is no physical relationship between current and power curves. Equations [1], [5], and [7] are shown on Figure 1 for comparison. In addition, a constant energy equation arbitrarily passing through the 20-hour discharge time is also shown.
The fact that the curves in Figure 1 deviate from the constant energy equation is related to the nonuniform electrochemical reactions in the porous plates. The mechanism for the loss in capacity of the cell as shown by the deviation from the constant energy line is still somewhat obscure. It appears that the basic electrode process of dissolution of lead ions and precipitation of lead sulfate is at the heart of the matter. Collins (2) presents a particularly clear discussion of electrode kinetics. Figure 2 shows the effect of current density on the distribution of lead sulfate in the discharged positive plate. Bode (1, p. 159) reports experimental work which shows that if the electrolyte is forced to flow through the plate during discharge, the loss in capacity at high current densities is recovered, i.e., the distribution of lead sulfate is uniform throughout the plate regardless of current density. It is not practical to use forced convection of electrolyte in a battery, so capacity equations which include reduction of capacity with increasing current or power must be used.

The effect of temperature on capacity based on work reported by Bode (1, p. 292) is shown in Figure 3. Bode (1, p.291) states a rule of thumb for the effect of temperature on capacity: there is an increase of capacity by 1 percent per degree Celsius rise. He also states that the thermal coefficient is $\alpha=0.008$ per degree Celsius for automotive LSI batteries according to the International Electrotechnical Commission (IEC). Both of the above values are somewhat larger than shown in Figure 3, and for accurate work the coefficient must be measured for the battery being used. The break in the curves in the region of -10 degrees Celsius corresponds to the temperature where the electrolyte begins to freeze. Figure 3 shows that the thermal coefficient is not a constant below the freezing point of the electrolyte. The effect of temperature on capacity is related to the diffusion and convection of electrolyte into the porous active mass and to a link with the formation of lead sulfate.

\section{BATTERY SIZING}

When considering a lead-acid battery for an electric wheelchair, one can consider the problem of sizing in two ways. First, for a given number of commercially available batteries of different capacity, it is necessary to select a battery that will have sufficient capacity between recharges. The second way is to consider the capacity needed and, knowing the capacity per positive plate of a particular design, calculate the number of positive plates which, with 


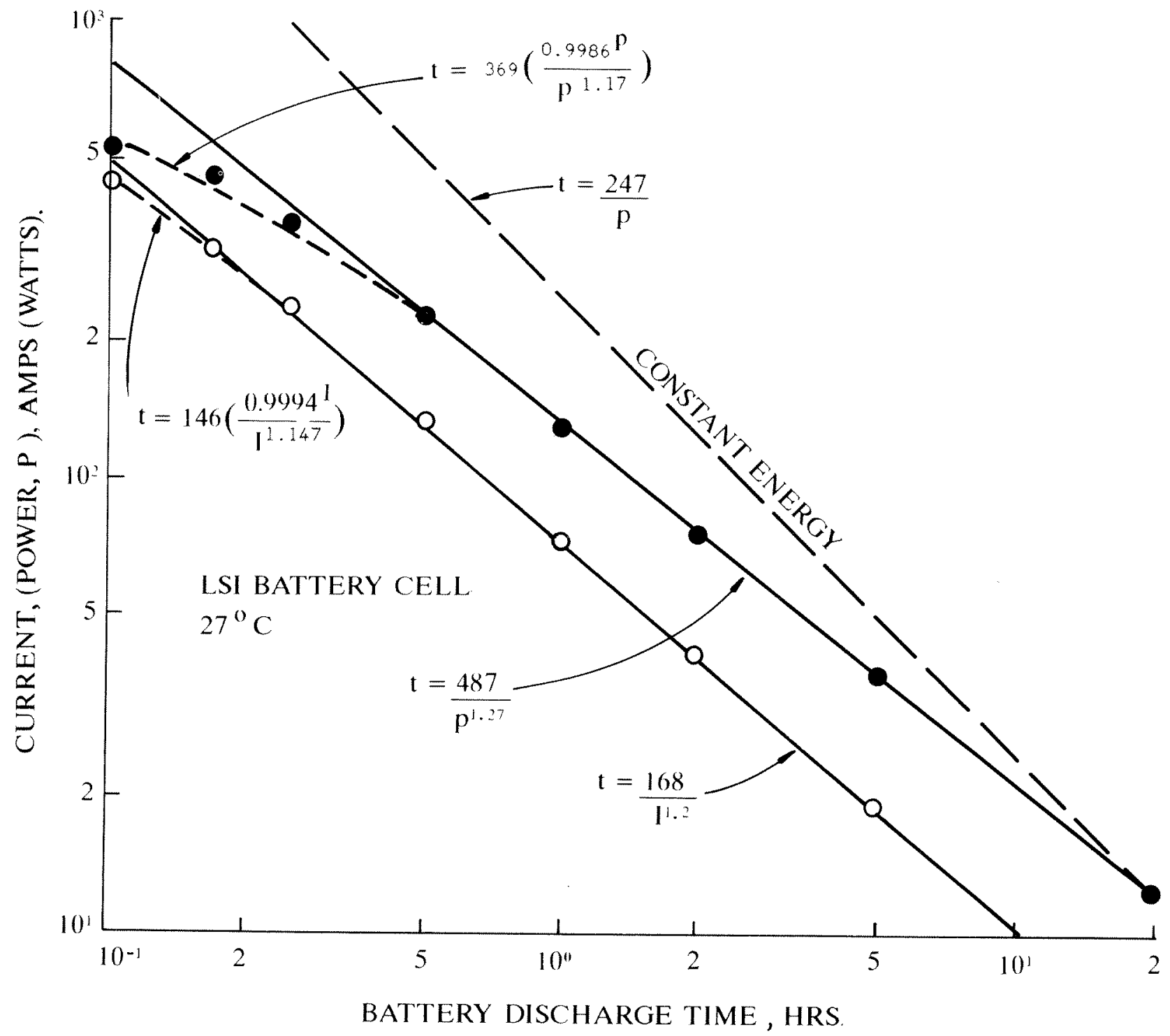

Figure 1.

Automotive LSI battery performance per cell, after Bode (1, p. 288) $100 \mathrm{~A}-\mathrm{H}, \mathrm{C} 5$.

the correct size of negative plates to form a cell, will supply the required capacity. In either case, the method of calculating the size depends on knowing the requirements in terms of electrical current or power placed upon the battery during discharge, called the duty cycle.

\section{Wheelchair duty cycle}

A three-step duty cycle for indoor and outdoor operation of an electric wheelchair was previously documented (7). In that paper, the power at the battery (which included all losses in the pulse-width-modulated controller and other wheelchair losses) was recorded and histograms of battery power demand prepared. Using the data tapes of power, the time interval was systematically reduced and histograms drawn. When the reduced time interval histogram deviated significantly from the total time histogram, the basic time interval for a duty cycle was chosen. This method produced a duty cycle of 60 seconds with three power levels plus off time, as shown in Table 1. For the indoor cycle the average load is 123 watts, or 5.1 amperes, and for the outdoor load it is 184 watts, or 7.7 amperes.

An indoor and outdoor two-step duty cycle was determined (9) based on measured performance of 24-volt electric wheelchairs, and is given in Table 2 . The average load for the indoor test in Table $\mathbf{2}$ is 19.2 watts, or 0.8 ampere, and for the outdoor test it is 129 watts, or 5.4 amperes. 
Journal of Rehabilitation Research and Development Vol. 27 No. 2 Spring 1990

Table 1.

Wheelchair duty cycles (7) 24 volts.

\begin{tabular}{ccccc}
\hline $\begin{array}{c}\text { Current } \\
\text { amperes }\end{array}$ & $\begin{array}{l}\text { Power } \\
\text { watts }\end{array}$ & $\begin{array}{l}\text { Power/cell } \\
\text { watts }\end{array}$ & $\begin{array}{l}\text { Time, indoor } \\
\text { seconds }\end{array}$ & $\begin{array}{l}\text { Time, outdoor } \\
\text { seconds }\end{array}$ \\
\hline 30.8 & 740 & 61.7 & 1.3 & 2.3 \\
17.9 & 430 & 35.8 & 9.9 & 15.2 \\
7.5 & 100 & 8.3 & 21.8 & 28.3 \\
0 & off & off & $\underline{27.0}$ & $\underline{14.2}$ \\
& & & 60.0 & 60.0 \\
\hline
\end{tabular}

Table 2 .

Wheelchair duty cycles (9) 24 volts.

\begin{tabular}{crrcr}
\hline $\begin{array}{c}\text { Current } \\
\text { amperes }\end{array}$ & $\begin{array}{c}\text { Power } \\
\text { watts }\end{array}$ & \multicolumn{1}{l}{$\begin{array}{l}\text { Power/cell } \\
\text { watts }\end{array}$} & $\begin{array}{l}\text { Time, indoor } \\
\text { seconds }\end{array}$ & $\begin{array}{l}\text { Time, outdoor } \\
\text { seconds }\end{array}$ \\
\hline 38.5 & 924 & 77.0 & 1.0 & \\
5.6 & 134 & 11.2 & 34.6 & \\
off & 0 & 0.0 & 253.4 & 3 \\
58 & 1392 & 116.0 & & 21 \\
13.5 & 324 & 27.0 & & 61 \\
off & 0 & 0.0 & & 85 \\
& & & 289.0 & \\
\hline
\end{tabular}

Tables 1 and 2 give similar average results for the outdoor test, but very different results for the indoor test. It is not felt that the difference between duty cycles for the indoor test are in error, just that the two cases represent the extremes for different users.

\section{Palmgren-Miner Rule}

In order to apply the results of the measurement of duty cycles to predict the discharge time for a particular battery (the first sizing approach), a method for taking into account the variation in power demand and time must be considered. Hoxie (3) presented an approach in 1954 that is still being used by the battery industry (8). In order to get good results with the Hoxie method, it is necessary to carefully consider each part of the duty cycle and in some cases a proper interpretation is necessary. A new method, called the revised Palmgren-Miner Rule method for variable loading, gives just as good results as the Hoxie method and the application is more straightforward. The PalmgrenMiner Rule method was applied to battery discharge under variable loading for the first time in 1983 (7). A revised method was used in this study. (For background details on the revised Palmgren-Miner Rule see references 4 and 5.)

We begin the analysis by considering the total capacity of the battery in terms of energy, watt-hours, which is a scalar function that equals the sum of the individual power demands on the battery during discharge by

$$
P_{\text {avg }} t=P_{1} t_{1}+P_{2} t_{2}+P_{3} t_{3}+\ldots \ldots
$$

where the $P_{i}$ are variable loads, and $t_{i}$ are the corresponding times for each load. Since $t$ is the total time for discharge of the battery, and for repeating duty cycles, it is convenient to define the time fraction as

$$
\beta_{\mathrm{i}}=\mathrm{t}_{\mathrm{i}} / \mathrm{t}
$$

Substituting the time fraction in Equation [8] gives

$$
\mathrm{P}_{\mathrm{avg}}=\Sigma_{\mathrm{i}} \beta_{\mathrm{i}} \mathrm{P}_{\mathrm{i}}
$$

The average power can be predicted for any repeating duty cycle. By knowing the power-time discharge curve, the total discharge time of a particular battery can be predicted. For example, consider the single cell battery of Figure 1 and the duty cycle from Table 1 for indoor operation of a wheelchair, where the average power per cell during discharge is calculated as follows

$$
\begin{gathered}
\mathrm{P}_{\text {avg }} / \text { cell }=61.7 \times 1.3 / 60+35.8 \times 9.9 / 60+8.3 \times \\
21.8 / 60+0 \times 27 / 60=10.3 \text { watts }
\end{gathered}
$$

\section{DISCHARGED AT}

1. $1.5 \mathrm{~mA} / \mathrm{cm}^{2}(20 \mathrm{~h})$

2. $6 "$ " (5h)

3. $30 " *(\mathrm{lh})$

4. $180 "$ " $(10 \mathrm{~min})$

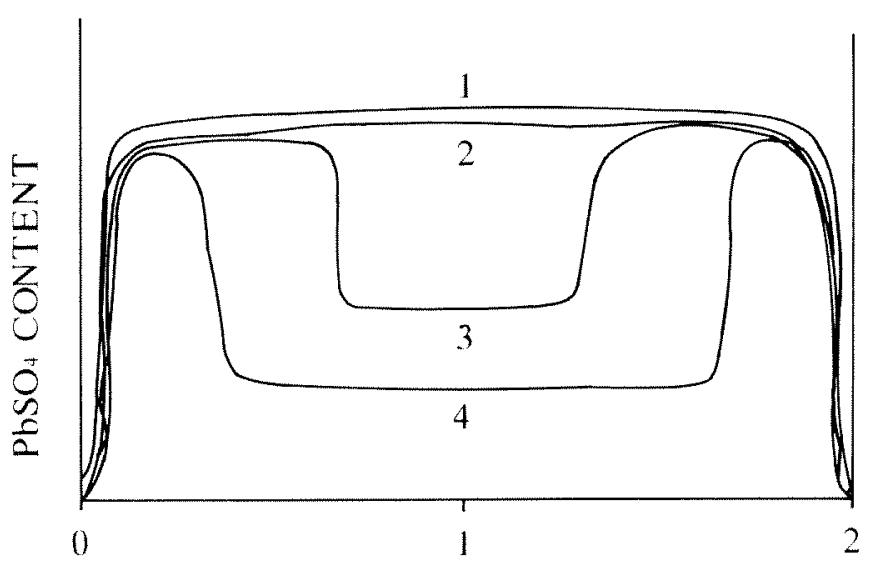

PLATE THICKNESS $(\mathrm{mm})$

Figure 2.

Lead sulfate distribution across the thickness of discharged positive plate, after Bode (1). 


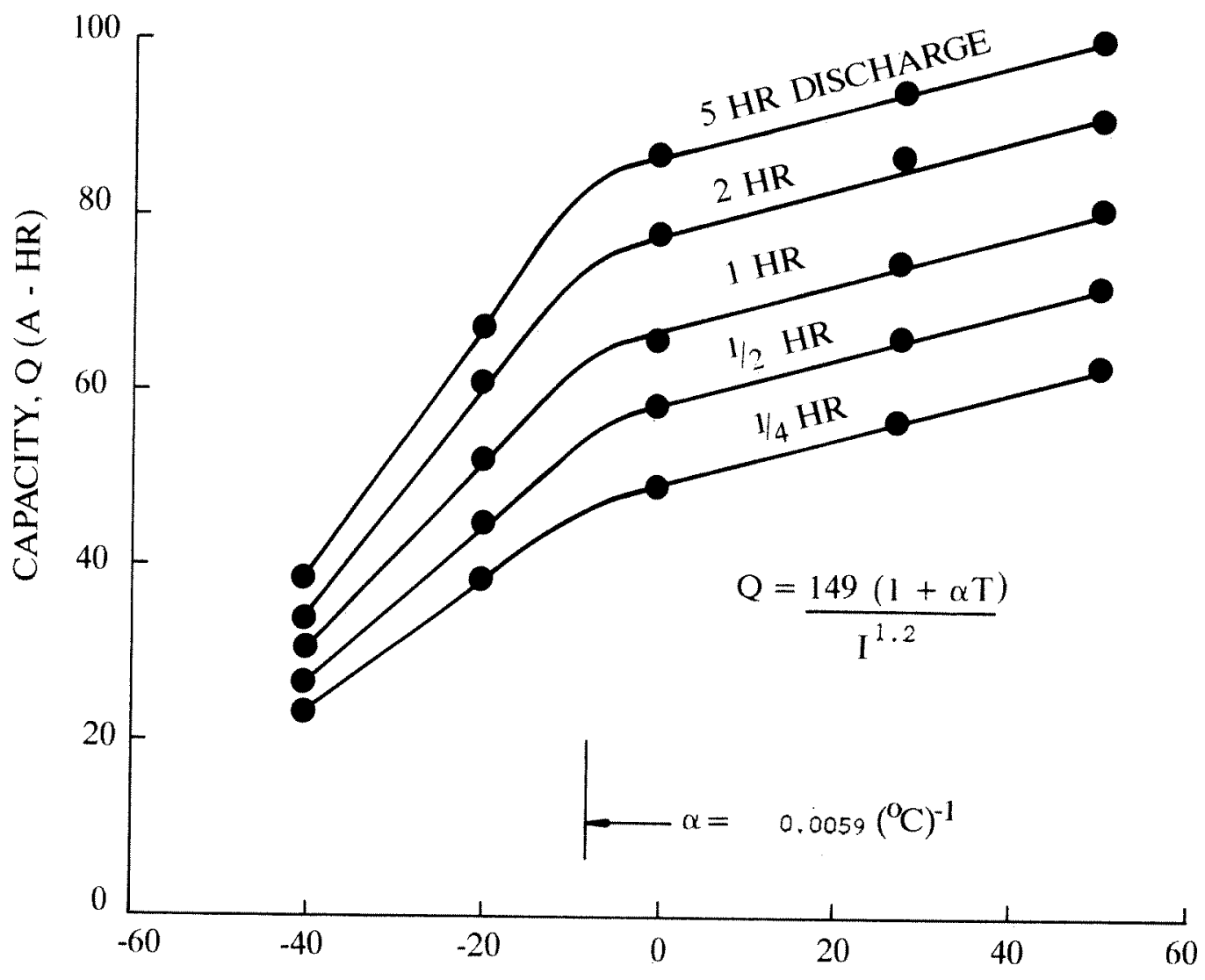

TEMPERATURE, $\mathrm{T}\left({ }^{\circ} \mathrm{C}\right)$
Figure 3.

Capacity versus temperature for LSI battery cell, after Bode (1, p. 288).
If the automotive LSI single cell shown in Figure 1 is to be considered for indoor use in the wheelchair, the discharge equation for the battery in Figure 1 can be used to get the total discharge time for the above duty cycle and is calculated as follows

$$
t=369 \times .9986^{10.3} / 10.3^{1.17}=23.75 \text { hours }
$$

An experimental verification of Equation [10] is shown in Figure 4. The battery used in previous work (7) is characterized by constant power DC discharge data (X), constant power pulse-width-modulated controller discharge $(\mathrm{O})$, and a particular DC driving cycle (duty cycle) shown by a square. The square point is the measured value for the total time of discharge during the repeated application of the driving cycle, and is plotted at the average value for the variable power loading. Thus, it is shown that the predicted value for total time at $\mathrm{P}_{\mathrm{avg}}$ is very close to the measured time, and certainly within the apparent accuracy of the different measurements for the battery.

Since the battery capacity equations are empirical, choosing to analyze the battery capacity in terms of ampere- hours rather than watt-hours and neglecting the changes in voltage, gives results within satisfactory experimental accuracy. For example, the same duty cycle examined above yields an average current of

$$
\mathrm{I}_{\text {avg }}=\Sigma_{\mathrm{i}} \beta_{\mathrm{i}} \mathrm{I}_{\mathrm{i}}=5.1 \text { amperes }
$$

and using the discharge equation from Figure 3 gives a prediction of the time of discharge as

$$
t=168 / 5.1^{1.2}=23.78 \text { hours }
$$

This result compares very well with the power calculation.

\section{Cell sizing}

The second approach to sizing is to determine the size of the battery in terms of positive plates required in each cell for the expected duty cycle and required time of discharge. An approach is given by Hoxie (3) and Migliaro (8), but they use a method which has certain difficulties when considering duty cycles with decreasing rate of discharge and complicated duty cycles. In this paper, the revised Palmgren-Miner Rule approach which is more 


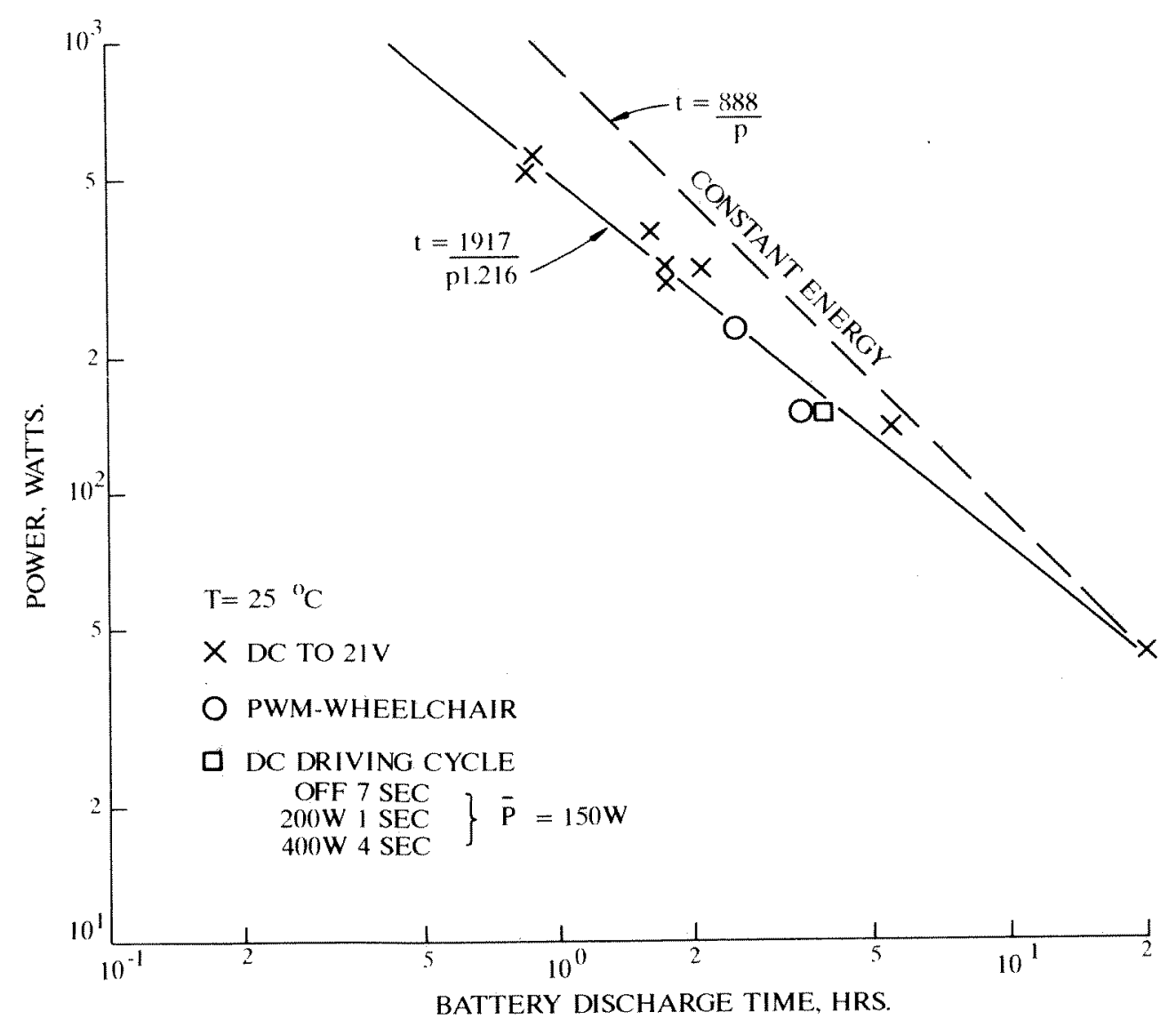

Figure 4.

Battery discharge performance $24 \mathrm{~V}, 37 \mathrm{~A}-\mathrm{H}, 9601$ "diehard" deep cycle. straightforward will be used.

By making use of Equation [4] and Equation [13] we can solve for the number of plates, $\mathrm{N}$, needed to deliver the average current required by the duty cycle for the required time of discharge. Equation [4] becomes

where

$$
\begin{gathered}
\mathrm{NB}^{\delta}=\mathrm{I}_{\mathrm{avg}}[\mathrm{t} /(\mathrm{A}(1+\alpha \mathrm{T}))]^{1 / \mathrm{n}} \\
\delta=\mathrm{I}_{\mathrm{avg}} /(\mathrm{n} \mathrm{N})
\end{gathered}
$$

It is necessary to solve Equation [15] by trial and error or by using standard computer techniques. An approximate equation explicit in $\mathrm{N}$ which gives values on the high side can be derived by using the first two terms of a series expansion of $\mathbf{B}^{\delta}$, which gives

$$
\mathrm{N}=\mathrm{I}_{\text {avg }}\left[(1-\mathrm{B}) / \mathrm{n}+\left(\mathrm{t} /(\mathrm{A}(1+\alpha \mathrm{T}))^{1 / \mathrm{n}}\right]\right.
$$

An example calculation can be demonstrated using the cell whose discharge curve at 27 degrees Celsius is shown in Figure 1. If it is assumed that the cell contains 10 positive plates, the constants for each positive plate are calculated to be

$$
\mathrm{A}(1+\alpha \mathrm{T})=10.35
$$

Now we will use Equation [15] to calculate the number of positive plates necessary to produce a cell which will carry the average current of the indoor duty cycle in Table 1 of 5.1 amperes for a total discharge time of 10 hours. For this problem $\delta=5.1 /(1.147 \times \mathrm{N})=4.4464 / \mathrm{N}$, and

$$
\mathrm{N} \times 0.9994^{4.4464 / \mathrm{N}}=5.1[10 / 10.35]^{1 / 1.147}=4.949
$$

By a trial and error calculation the number of positive plates is

$$
\mathrm{N}=4.95 \text { positive plates }
$$

Thus, a 5 positive plate-per-cell lead-acid battery with a discharge curve similar to that shown in Figure 1 would satisfy the design requirements of the cell.

\section{BATTERY LIFE}

The lead-acid storage battery life in terms of usable cycles of charge and discharge is characterized by sudden and complete failure due to mechanical breakdown or elec- 


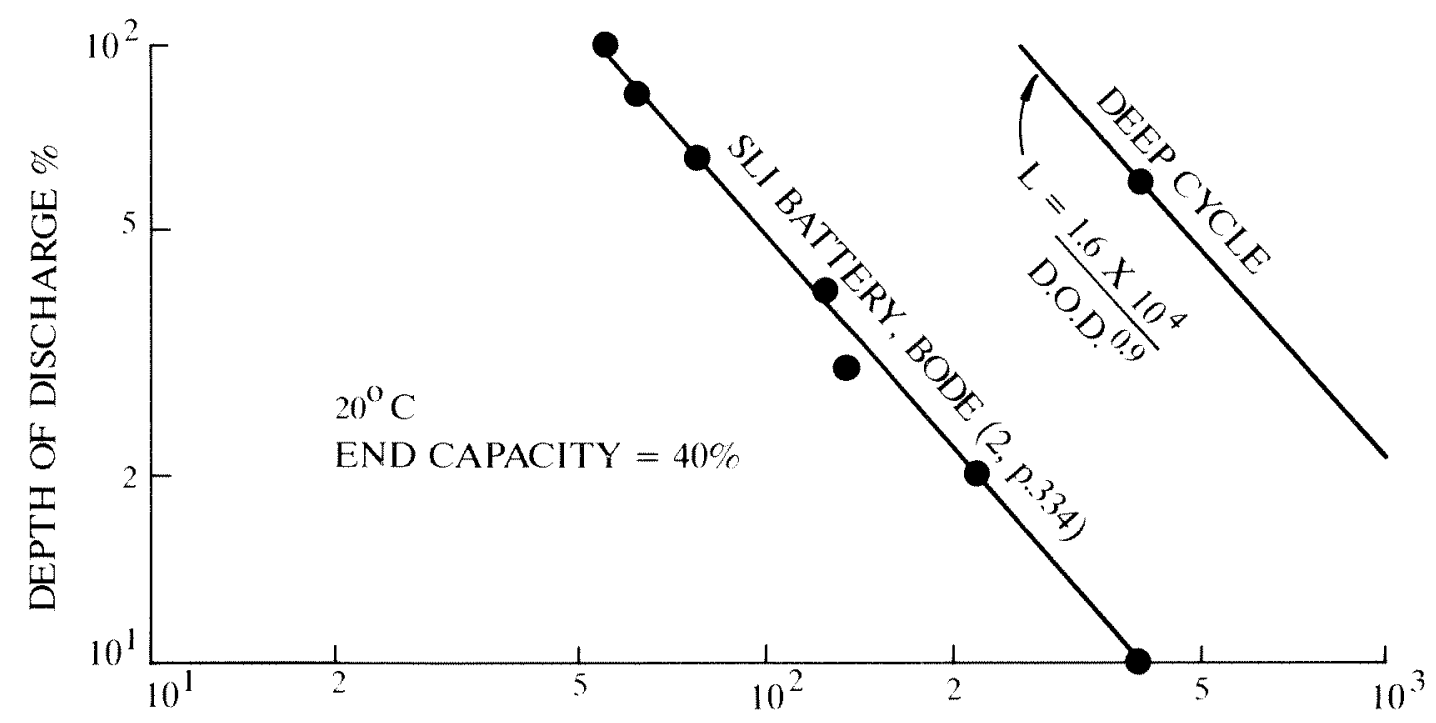

SECOND LIFE, CYCLES

Figure 5.

Operational life versus depth of discharge.

trolyte leakage, and a slow decrease in capacity per cycle to an unusable level of capacity such as being unable to start an engine in the case of an automotive LSI battery. Neglecting mechanical failures, since they are often due to the quality of manufacture, the slow decrease in capacity is associated with: 1) sludging of the positive mass; 2) destruction of the positive grid; and, 3) defects in the negative mass and separators $(1, \mathrm{p} .334)$.

The life of the battery is influenced by temperature, acid density, overcharge practice, and depth of discharge (DOD). Of these factors, DOD has a very pronounced effect on the life of the battery.

Depth of discharge is defined as the percent of removed capacity during one discharge-charge cycle related to the average initial capacity of the first discharges. During testing the DOD is controlled for each cycle of discharge and recharge. Now and then a full discharge to a specified depth, i.e., 60 percent DOD or 40 percent capacity, is run to determine if the end of life in terms of available capacity has been reached. This type of testing is called second life (1, p.333). Some tests of an automotive LSI battery by Bode (1) and a data point for a deep cycle battery reported by Kauzlarich et al. (7, Table 1) are shown on Figure 5. In Figure 5 we see that the life of a battery is significantly affected by the DOD, with life falling by a factor of 10 if the DOD changes from 10 percent to 100 percent. This effect is the main reason automotive LSI batteries show a very long life in automobiles, where the generator of the car keeps topping up the battery so that the average depth of discharge is low, but a very short life if used in a wheelchair where the DOD for each day's use is on the order of 100 percent. Figure 5 shows the advantage in increased life for a deep cycle lead-acid battery, and it is this battery that is recommended for wheelchair use.

A relation between DOD and battery cost, originally considered by Kauzlarich et al. (7, Appendix C), will be analyzed here. It was found that the cost for deep cycle 24-volt lead-acid batteries in 1987 varied approximately linearly with capacity $\mathrm{C}$ in ampere-hours as follows:

$$
\$=86+0.9 \times \mathrm{C}
$$

The DOD, in terms of capacity, is defined by the equation

$$
\mathrm{DOD}=\left(\mathrm{C}_{0} / \mathrm{C}\right) \times 100
$$

Making use of the life-DOD equation for deep cycle batteries from Figure 5 and Equations [21] and [22] results in the following equation for cost per cycle:

$$
\$ / \text { cycle }=1.6 \times 10^{-4} \times\left[\left(\mathrm{C}_{0} / \mathrm{C}\right) \times 100\right]^{0.9}(86+0.9 \times \mathrm{C})
$$

It was determined that the average capacity used each day for outdoor use of an electric wheelchair was 20 amperehours (A-H), at an average current of 5.4 amperes, or 130 watts (9). Using Equation [23] based on a $C_{o}=20 \mathrm{~A}-\mathrm{H}$, and letting the capacity, $\mathrm{C}$, of the battery increase, there 
Journal of Rehabilitation Research and Development Vol. 27 No. 2 Spring 1990

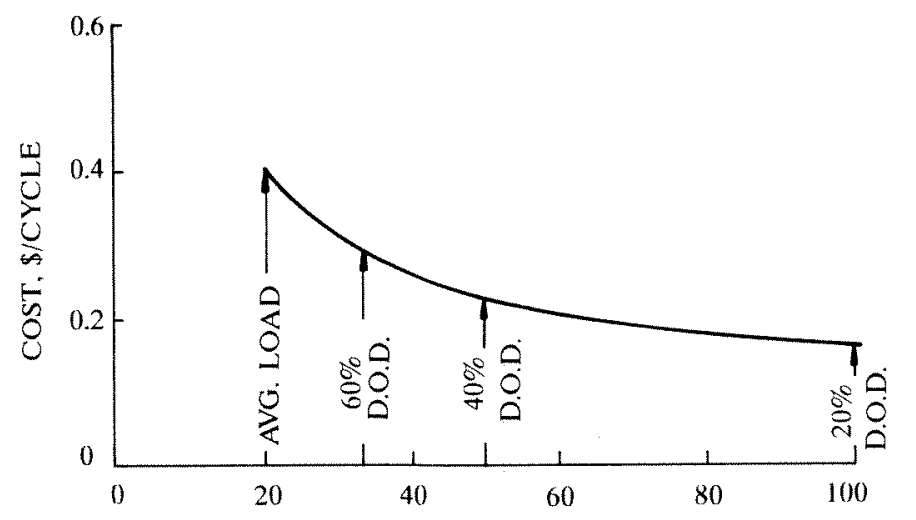

BATTERY CAPACITY, A-H.

\section{Figure 6.}

Cost advantage per cycle for using a battery with a larger capacity than needed.

is an improvement in cost per cycle for using a battery with greater capacity than the basic per day requirement, as shown in Figure 6. For example, Figure 6 assumes that the battery is recharged every day so that the daily DOD, which would be 100 percent for a $20 \mathrm{~A}-\mathrm{H}$ battery, is only 20 percent for a $100 \mathrm{~A}-\mathrm{H}$ battery. One could use a larger battery than needed (the $100 \mathrm{~A}-\mathrm{H}$ battery), recharge it every 5 days, and get a little better cost per day than shown in Figure 6. However, in our experience the best advice is to recharge every day to be sure the battery is not too deeply discharged. Very deep discharge can lead not only to fewer cycles of life but sometimes to difficulty in recharging the battery.

\section{BATTERY SELECTION}

When purchasing a battery from a catalogue of commercially available batteries one should select the lead-acid wet cell, deep cycle (deep discharge, golf cart, or boat) battery because it will be the most economical and is the type recommended by wheelchair manufacturers. Though not available in the United States, the tubular positive plate battery is the most economical for wheelchair use. If the wheelchair is taken on an aircraft it must be equipped with a battery allowed on aircraft, such as a gelled cell or a starved electrolyte battery.

The typical wheelchair requires two 12-volt batteries to be connected in series on the wheelchair, with limitations on the size of batteries that can be mounted in the battery carrier. In general, the rating of the battery should be at least 37 ampere-hours (one of the standard sizes of batteries) at the 20-hour rate. A 37 ampere-hours battery (20-hour rating) is shown in Figure 4. At the outdoor average power of 130 watts, this size battery will operate continuously for 5 hours and deliver 27 ampere-hours at 100 percent DOD. Any larger capacity battery that can be mounted on the wheelchair will prove to be more economical, as shown in Figure 6.

For long life, the liquid level in the battery must be maintained and the battery kept charged, but not overcharged. A charger with an automatic cut-off is highly recommended to avoid overcharging.

\section{ACKNOWLEDGMENTS}

This work was supported by the National Institute on Disability and Rehabilitation Research, Grant H133E80003-88, and the University College of Swansea, Tribology Centre, Wales, U.K.

\section{REFERENCES}

1. Bode H: Lead-acid Batteries. New York: John Wiley \& Sons, 1977.

2. Collins DH (Ed.): Lead-acid batteries. $J$ Power Sources 2(1):1-24, 1977. (Also published as a reference and data book by Elsevier Sequoia S.A., Lausanne, 1977).

3. Hoxie EA: Some discharge characteristics of lead acid batteries. AlEE, Applications \& Industry (Industry Applications) 11:17-22, 1954.

4. Kauzlarich JJ: An improved fatigue life prediction for rolling element bearings with fluctuating loads. In Proceedings of 5th International Congress on Tribology, Helsinki, 2:263-268, 1989.

5. Kauzlarich JJ: The Palmgren-Miner Rule derived. In Proceeding of the 15th Leeds/Lyon Symposium on Tribology, $5,1988$.

6. Kauzlarich JJ, Junkmann BC: A new battery with very long life for electric wheelchairs. In Proceedings of the 10th Annual RESNA Conference, 501-503. Washington, DC: Association for the Advancement of Rehabilitation Technology, 1987.

7. Kauzlarich JJ, Ulrich V, Bresler M, Bruning T: Wheelchair batteries: Driving cycles and testing. J Rehabil Res Dev 20(1):31-43, 1983.

8. Migliaro MW: Sizing batteries for generating stations. IEEE Trans Energy Convers 1(4):25-30, 1986.

9. Petersen HA: Development of test procedures for batteries in electric wheelchairs. Report No. 86022, Energy Research Laboratory, Niels Bohrs Alle 25, 5230 Odense M, Denmark, 1986. 